\title{
Effect of time of supplementary feeding on intake, apparent digestibility and rumen fermentation of grass hay by sheep
}

\author{
M. D. Carro ${ }^{+}$, A. R. Mantecón $¥$, I. A. Wright and I. J. Gordon \\ Macaulay Land Use Research Institute, Craigiebuckler, Aberdeen AB9 2QJ
}

\begin{abstract}
Effects of time of supplementation on forage intake, nutrient apparent digestibility and rumen fermentation were studied with 12 mature castrated male sheep (wethers) offered grass hay from $16.30 \mathrm{~h}$ to $09.30 \mathrm{~h}$ and supplemented with a cereal-based concentrate given at either 09.30 or $16.00 \mathrm{~h}$. Voluntary intake of hay organic matter (OM) was decreased by feeding the concentrate $(\mathrm{P}<0.01)$. Offering concentrate at $09.30 \mathrm{~h}$ after hay was available, increased intake of hay and total OM compared with offering it at $16.00 \mathrm{~h}$ before hay was available $(\mathrm{P}<0.05)$. Daily pattern of hay intake was not changed when concentrate was offered at $09.30 \mathrm{~h}$ compared with feeding hay alone, but concentrate given at $16.00 \mathrm{~h}$ resulted in a lower hay intake between 16.30 and $18.00 \mathrm{~h}$. Sheep offered concentrate at $09.30 \mathrm{~h}$ had higher rumen ammonia levels than those offered concentrate at $16.00 \mathrm{~h}$, but there were no differences in the apparent digestibility of the nutrients, rumen $\mathrm{pH}$ and molar proportions of the main volatile fatty acids. There were also no differences between groups in the blood plasma concentrations of 3-hydroxybutyrate (3OHB), nonesterified fatty acids (NEFA) and glucose. It is concluded that feeding supplement after rather than before a period of intake of forage or a bout of grazing may offer a means of minimizing reduction of forage intake as a consequence of feeding concentrate.
\end{abstract}

Keywords: concentrate, digestion, eating pattern, hay, sheep.

\section{Introduction}

In situations where optimum sward conditions cannot be maintained, and the nutrient intake of animals falls below the required level, one option available is to provide supplementary feeding. Supplements are usually offered in the morning, when the animals have just completed the first grazing session. The frequency of feeding supplements has been examined in several studies (see Allden, 1981), but little is known about the effect of time of supplementation on the daily pattern of herbage intake. The normal daily pattern of grazing consists of major grazing periods beginning near dawn and again in the late afternoon, ending near sunset, with minor sessions during the remainder of the day (Arnold, 1981).

\footnotetext{
+ Present address: University of León, 24007, León, Spain. ¥ Present address: Estación Agrícola Experimental, C.S.I.C., Apartado 788, 24080 León, Spain.
}

The aim of this experiment was to investigate whether the timing of feeding a concentrate supplement, in relation to whether this was preceded or followed by intake of forage, had an influence on the pattern of intake of the forage component of the diet.

To ensure control of pattern of forage availability animals were fed indoors on hay. Measurements of pattern of hay intake and of rumen $\mathrm{pH}$, ammonia and volatile fatty acids and blood metabolites were carried out.

\section{Material and methods}

Animals and experimental design

Twelve mature Scottish Blackface castrated male sheep (wethers), averaging 53.9 (s.e. 6.70$) \mathrm{kg}$ live weight and 2.5 (s.e. 0.20 ) body condition score, were divided into two groups (treatments $\mathrm{A}$ and $\mathrm{M}$ ) of six animals, according to live weight and body 
condition, and housed in individual pens, with no bedding material.

The experiment consisted of a pre-experimental and experimental phase each of 20 days duration; each was divided into a 10-day period to allow adaptation to the diet and a 10-day period during which measurements were carried out.

Chopped grass hay was offered ad libitum to all animals throughout the pre-experimental and experimental phases from $16.30 \mathrm{~h}$ until $08.30 \mathrm{~h}$. At this time the refusals were removed and fresh hay was offered for $1 \mathrm{~h}$. Thus no hay was available from $09.30 \mathrm{~h}$ to $16.30 \mathrm{~h}$ in order to promote a high rate of intake in the morning and late afternoon, to mimic the diurnal pattern of intake in grazing animals.

During the pre-experimental phase the animals were offered only hay. During the experimental phase a cereal-based concentrate supplement was offered. Half the sheep were given supplement in the morning at $09.30 \mathrm{~h}$ (treatment $\mathrm{M}$ ) and half in the afternoon at $16.00 \mathrm{~h}$ (treatment $\mathrm{A}$ ) at the rate of $700 \mathrm{~g}$ per sheep per day. Sheep consumed all of the offered concentrate within 15 min of feeding. All sheep had free access to water during the experiment.

The composition of the concentrate is shown in Table 1 , while the chemical composition of the hay and concentrate is given in Table 2 .

\section{Measurements}

Voluntary intake was measured during the last 10 days of each period, during which time hay was offered at an amount proportionately 0.10 to 0.15 in excess of the previous day's consumption. Samples of food offered to and refused by the animals were taken, bulked over the 10-day measurement period and stored for subsequent analysis.

On 2 days consecutively in each measurement period the pattern of hay intake was measured by weighing refusals at $18.00,21.00,24.00,03.00,06.00,08.30$ and $09.30 \mathrm{~h}$.

In order to measure the apparent digestibility of the total diet, a total collection of faeces was made for the last 8 days of each experimental period, when the sheep were equipped with faecal collection bags. A representative sample of faeces was taken daily, dried at $60^{\circ} \mathrm{C}$ in a forced-air oven and stored for subsequent analysis.

On the last day of the second period, rumen fluid samples were obtained at 12.00, 18.00, 24.00 and $06.00 \mathrm{~h}$ using a stomach tube. Care was taken to avoid excessive contamination with saliva, and
Table 1 Composition of concentrate ( $g / k g$ fresh weight)

\begin{tabular}{lr}
\hline \hline Barley & $419 \cdot 1$ \\
Malt culms & $208 \cdot 0$ \\
Rapeseed meal & $100 \cdot 0$ \\
Condensed molasses solubles (0.2 molasses) & $70 \cdot 0$ \\
Dark grains & $68 \cdot 0$ \\
Dry fat (0.5 lipid) & $50 \cdot 0$ \\
Fish meal & $50 \cdot 0$ \\
Fat protector & $10 \cdot 0$ \\
Limestone & $9 \cdot 6$ \\
Salt & 9.2 \\
Calcined magnesite & 3.2 \\
Minerals/vitamins & 2.5 \\
Dibasic calcium phosphate & 0.4 \\
\hline \hline
\end{tabular}

Table 2 Chemical composition of grass hay and concentrate

\begin{tabular}{lcc}
\hline \hline & Hay & Concentrate \\
\hline Dry matter (DM; g/kg) & 838 & 925 \\
Composition of DM (g/kg) & & \\
Organic matter (OM) & 927 & 909 \\
Crude protein (CP) & 105 & 196 \\
Starch & + & 246 \\
Sugar & + & 53 \\
Neutral-detergent fibre & 626 & 267 \\
Acid-detergent fibre & 386 & 135 \\
\hline \hline
\end{tabular}

+ Not available.

samples were large enough to minimize any potential effect of contamination. The $\mathrm{pH}$ of the sample was measured immediately following collection and the sample was then strained through four layers of cheesecloth, acidified with $0.5 \mathrm{~mol} / 1$ sulphuric acid and frozen until analysis for volatile fatty acids (VFA) and ammonia.

Blood samples were collected into heparinized tubes by jugular venipuncture at 12.00, 15.00, 18.00, 21.00, $24.00,03.00,06.00$ and $09.00 \mathrm{~h}$ on 2 days consecutively in the second period. Following centrifugation plasma was removed and stored at $-20^{\circ} \mathrm{C}$ until determination of 3-hydroxybutyrate (3OHB), non-esterified fatty acids (NEFA) and glucose.

\section{Chemical analyses}

Dry matter (DM) concentration of foods, refusals and faeces was determined by drying samples to constant weight at $100^{\circ} \mathrm{C}$ and organic matter (OM) calculated as weight lost during ashing at $550^{\circ} \mathrm{C}$. Nitrogen $(\mathrm{N})$ concentration was determined by a macro-Kjeldahl method. Neutral-detergent fibre (NDF) and aciddetergent fibre (ADF) were determined using the method of Goering and Van Soest (1970). Rumen fluid ammonia was determined as described by Whitehead, Cooke and Chapman (1967) and VFA by 
gas chromatography (Ottenstein and Bartley, 1971). Blood samples were analysed for $3 \mathrm{OHB}$ using the method described by Zivin and Snarr (1973); for glucose using a modification of the method described by Richardson (1977); and for NEFA using a kit (NEFA C kit, Wako Chemicals GmbH, Germany).

\section{Statistical analysis}

Intake and apparent digestibility data were analysed by analysis of variance, with intake in period 1 as a covariate using the ANova procedure of the Statistical Analysis Systems Institute (SAS, 1982). Ruminal fermentation parameters and blood metabolites were analysed by ANOVA (SAS, 1982) with time of concentrate feeding as the main effect.

\section{Results}

Voluntary intake of hay DM was lower when concentrate was given in the experimental phase than when no concentrate was offered in the preexperimental phase (1026 v. 772 (s.e. 34.1) g/day; $P<0.001)$. Table 3 shows the voluntary intake of hay when the sheep were given the concentrate at $09.30 \mathrm{~h}$ (M) or at $16.00 \mathrm{~h}(\mathrm{~A})$.

Table 3 Effects of time of supplementation on voluntary intake of hay

\begin{tabular}{|c|c|c|c|}
\hline & \multicolumn{3}{|c|}{ Time of supplementationt } \\
\hline & M & A & s.e. \\
\hline \multicolumn{4}{|l|}{ Hay intake } \\
\hline Organic matter intake (g/day) & 860 & $686^{*}$ & 55.7 \\
\hline Crude protein intake(g/day) & 108 & $80^{*}$ & 6.5 \\
\hline \multicolumn{4}{|c|}{$\begin{array}{l}\text { + M: concentrate given at } 09.30 \mathrm{~h} \text {; A: concentrate given at } \\
16.00 \mathrm{~h} \text {. }\end{array}$} \\
\hline \multicolumn{4}{|c|}{$\begin{array}{l}\text { Table } 4 \text { Effect of time of supplementation on diumal pattern of hay } \\
\text { intake ( } g \text { dry matter) }\end{array}$} \\
\hline & \multicolumn{3}{|c|}{ Time of supplementationt } \\
\hline & M & A & s.e. \\
\hline \multicolumn{4}{|l|}{ Time } \\
\hline $16.30-18.00$ & 514 & $299 * *$ & 28.5 \\
\hline $18.00-21.00$ & 221 & 192 & $20 \cdot 1$ \\
\hline $21.00-24.00$ & 144 & 142 & 14.5 \\
\hline $24.00-03.00$ & 118 & 148 & $13 \cdot 2$ \\
\hline $03.00-06.00$ & 94 & 80 & 8.0 \\
\hline $06.00-08.30$ & 67 & 82 & $7 \cdot 3$ \\
\hline $08 \cdot 30-09.30$ & 108 & 108 & 13.1 \\
\hline
\end{tabular}

+ M: concentrate given at $09.30 \mathrm{~h} ; \mathrm{A}$ : concentrate given at $16.00 \mathrm{~h}$.
The sheep on treatment $\mathrm{A}$ had lower intakes of hay OM than those on treatment $M(P<0.05)$. Time of supplementation had no significant effect on the apparent digestibility of OM in the total diet $(0.712 v$. 0.696 (s.e. 0.0084 ), $P>0.05$ for $\mathrm{M}$ and $\mathrm{A}$ treatments respectively) or on digestion of NDF or ADF.

The diurnal pattern of hay DM intake is shown in Table 4. Feeding the concentrate in the afternoon reduced hay DM intake by $215 \mathrm{~g}$ between 16.30 and $18.00 \mathrm{~h}$ compared with feeding the concentrate in the morning $(P<0.01)$. However, there were no differences in DM intake between the treatments at other times of the day.

Figure 1 shows the effect of time of supplementation on rumen $\mathrm{pH}$ and ammonia concentrations. Samples obtained at $12.00 \mathrm{~h}$ from treatment $\mathrm{A}$ had a significantly higher ruminal $\mathrm{pH} \quad(7.23$ 0. 6.79; $P<0.001$ ) and a significantly lower ammonia concentration (112 v. $149 \mathrm{mg} / \mathrm{l} ; P<0.05)$ than those from treatment $M$. There were no significant differences between groups in these parameters at other sampling times.

Time of supplementation failed to change significantly molar proportions of acetate $(70.8$ (s.e. $0.45) \mathrm{mol} / \mathrm{l}$ ) and propionate $(17.2$ (s.e. 0.34$) \mathrm{mol} / \mathrm{l}$ ) at any sampling times. However, molar proportions of butyrate and valerate were lower in the samples obtained at $12.00 \mathrm{~h}$ from treatment $\mathrm{A}$ than those from treatment $\mathrm{M}$ (Figure $2 ; P<0.05$ ). The concentration of isoacids was lower in treatment $A$ at $06.00 \mathrm{~h}$ $(P<0.05)$ and at $12.00 \mathrm{~h}(P<0.001)$.

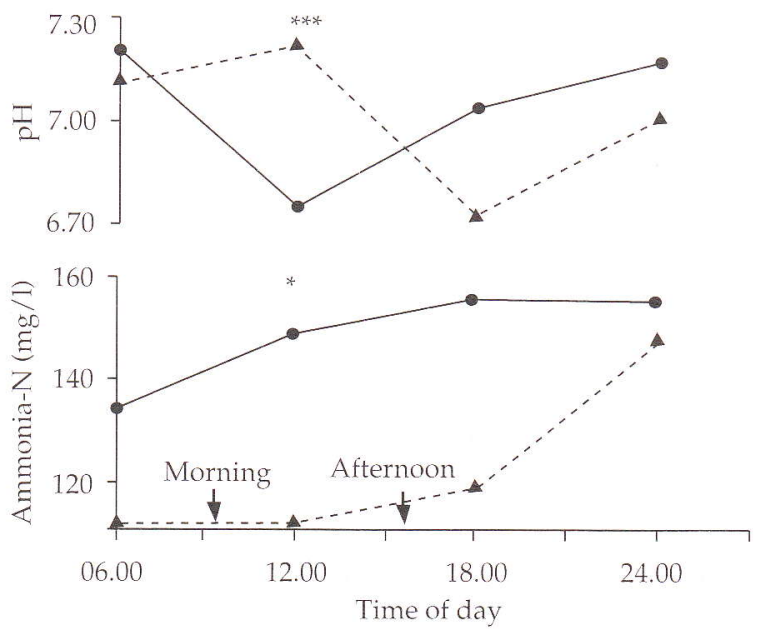

Figure 1 Rumen $\mathrm{pH}$ and ammonia concentrations at different times of day for sheep given supplement in the morning (—) or afternoon (_- 

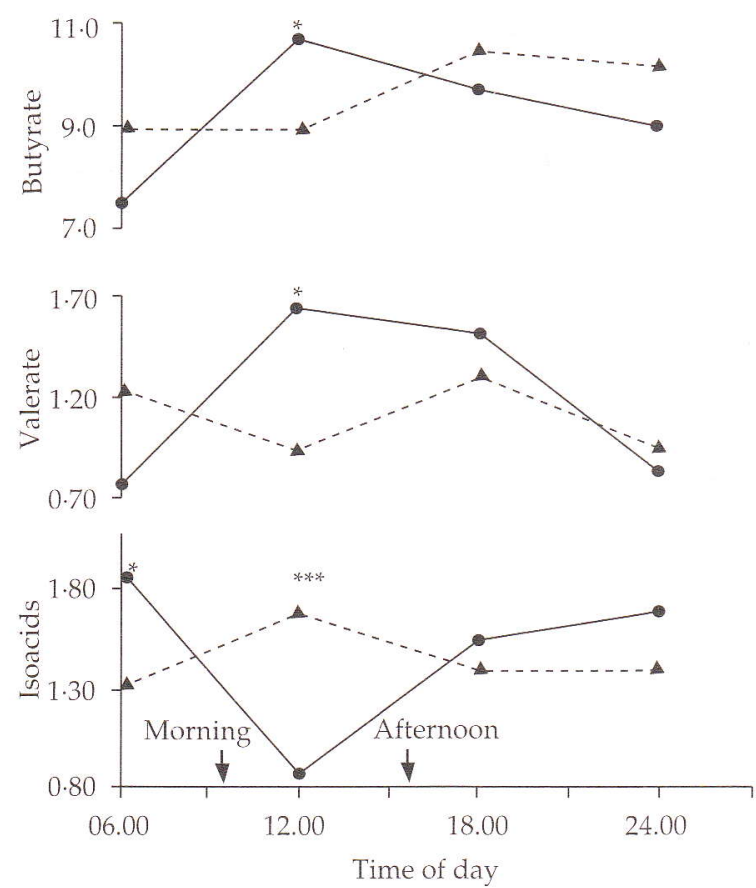

Figure 2 Rumen butyrate, valerateand iso-acid concentrations at different times of day for sheep given supplement in the morning

Plasma concentrations of NEFA, glucose and $30 \mathrm{HB}$ are shown in Figure 3. After the feeding of the supplement concentrations of glucose and $3 \mathrm{OHB}$ rose while concentrations of NEFA fell. This resulted in differing diurnal patterns for these blood metabolites between the two treatments.

\section{Discussion}

The diurnal pattern of hay intake is shown more clearly when the hay-DM intake in each of the measured time intervals is expressed as a proportion of the daily intake (Figure 4). The highest proportion of hay intake occurred between 16.30 and $18.00 \mathrm{~h}$ with a steady decline from 18.00 to $08.30 \mathrm{~h}$ and a slight increase from 08.30 to $09.30 \mathrm{~h}$.

The method of feeding hay was partly successful in mimicking the diurnal pattern of intake seen in grazing animals (Arnold, 1981). It promoted a high proportion of the total daily intake in late afternoon, but there was only a small increase in the proportion of intake occurring between 08.30 and $09.30 \mathrm{~h}$.

The pattern of hay intake differed between the A and $\mathrm{M}$ treatments. The proportion of daily intake
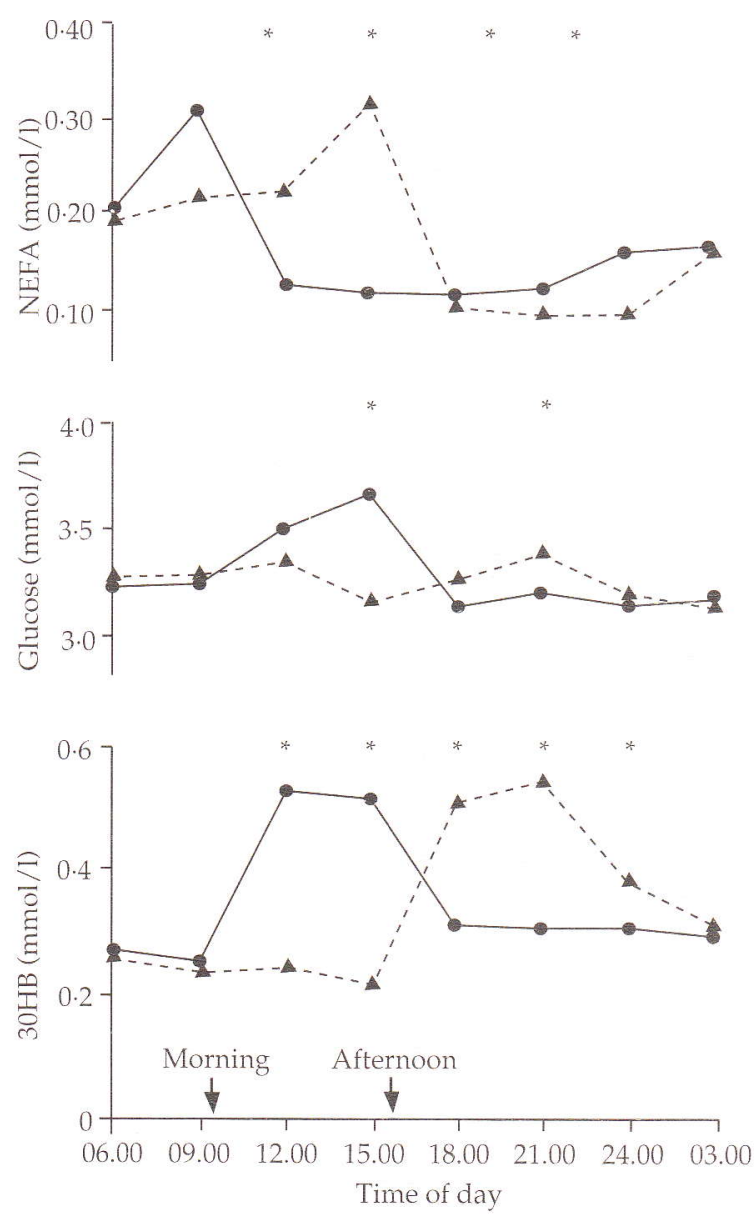

Figure 3 Plasma concentrations of non-esterified fatty acid (NEFA), glucose and 3-hydroxybutyrate (3OHB) at different times of day for sheep given supplement in the morning (ㄴ) or afternoon (

between 16.30 and $18.00 \mathrm{~h}$ was lower when animals were offered the concentrate in the afternoon $(0.25 \mathrm{v}$. 0.41 for the $\mathrm{A}$ and $\mathrm{M}$ treatments respectively). This may have been due to the high ruminal digesta fill in the A sheep in this period; animals consumed $700 \mathrm{~g}$ concentrate within $15 \mathrm{~min}$ of feeding and, as a consequence, may not have been able to achieve a high subsequent intake of hay.

Overall, animals given concentrate in the morning had a significantly higher total intake of digestible $\mathrm{OM}(881$ and $1041 \mathrm{~g} /$ day $(P<0.05)$ for the $\mathrm{A}$ and $\mathrm{M}$ groups, respectively). Similar results were reported by Howard, Muntifering, Howard and Hayek (1992), who found that offering supplement to hay-fed sheep at $08.00 \mathrm{~h}$ resulted in a higher total DM intake than offering supplement at $15.00 \mathrm{~h}$. 


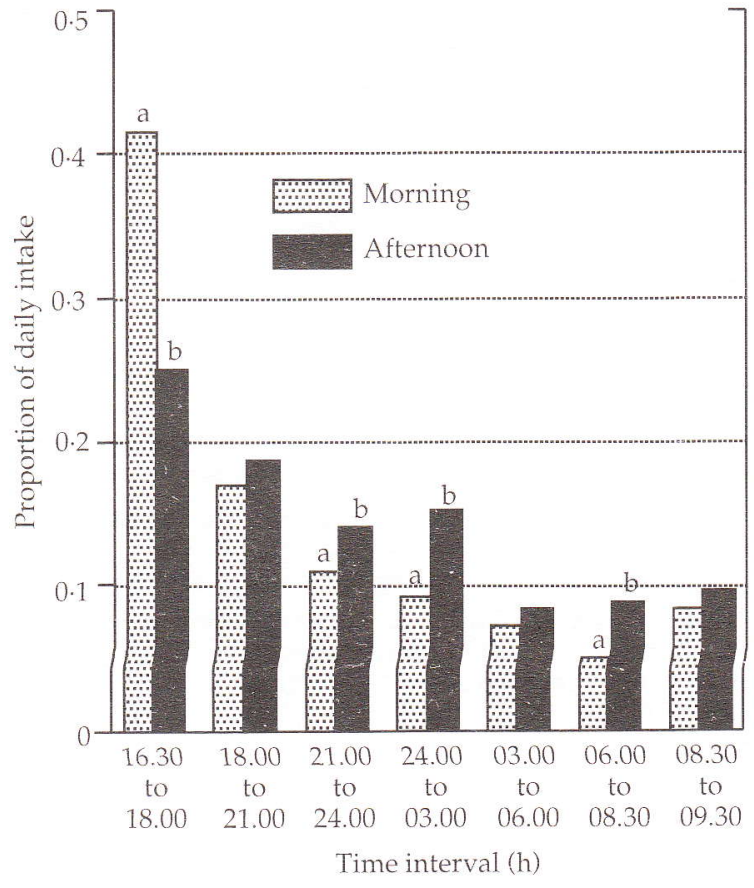

Figure 4 Proportion of total daily intake of hay consumed in different time intervals for sheep fed in the morning or afternoon. Within time intervals different letters indicate significant differences $(P<0.05)$.

It might be expected that animals given the concentrate after hay ( $M$ group) and in which digestion was spread out over a longer time interval (in which no food was available), would utilize absorbed nutrients more efficiently since substrates would be available more continuously (Milligan, 1971). Some authors (Palmquist, Smith and Ronning, 1964; French and Kennelly, 1990) have reported improved daily gains and food conversion efficiencies when patterns of food administration similar to that used for the $\mathrm{M}$ group were used. However the short duration of the experiment precludes any conclusions being made on likely effects on live-weight gain.

In agreement with the results of Howard et al. (1992), time of supplementation had no effect on the mean value of ruminal $\mathrm{pH}$, but in both groups ruminal $\mathrm{pH}$ decreased after feeding the concentrate. However it was always higher than 6.5 , the critical level below which cellulolytic activity is depressed (Stewart, 1977). Kaufmann (1976) reported that a satisfactory regulation of rumen $\mathrm{pH}$ is achieved with a minimum proportion of 0.40 roughage in the diet and in this experiment the ratio hay:concentrate of the diet (DM basis) ranged from $56: 44$ to $69: 31$.
Although the difference was only significant at $12.00 \mathrm{~h}$ ruminal ammonia concentration was higher in sheep given concentrate in the morning compared with those given concentrate in the afternoon. This may have been due to the higher intake of hay and therefore total crude protein intake for the $\mathrm{M}$ group than for the A group. It might be expected that the increased ammonia concentrations would promote more extensive microbial growth and forage degradation (DelCurto, Cochran, Harmon, Beharka, Jacques, Towne and Vazant, 1990) in the M group. The exact nature of the response will depend on the concentration and degradability of protein in both the forage and concentrate. Although not significant $(P=0.20)$ apparent digestibility of cell wall (NDF) tended to be higher for the M group (0.663) than for the A group (0.633). It is possible that there were differences in the ruminal NDF digestion, but postruminal digestion may have prevented their detection. Howard et al. (1992) reported that offering supplement to hay-fed sheep at $08.00 \mathrm{~h}$ resulted in a higher digestion of ADF than offering supplement at $15.00 \mathrm{~h}$, but time of supplementation had no effect on digestion of NDF.

In both groups of animals molar proportions of acetate were decreased and molar proportions of propionate and butyrate were increased after feeding the concentrate. The method of obtaining rumen samples in this experiment prevented frequent measurement to obtain an accurate assessment of the pattern of rumen molar proportions of VFA with the two times of supplementation used.

In agreement with the results reported by Sutton, Hart, Broster, Elliott and Schuller (1986), both glucose and $3 \mathrm{OHB}$ concentrations in the plasma increased after feeding the concentrate (Figure 3), the increase being similar for both treatments. Plasma NEFA concentrations decreased after feeding the concentrate, probably as a consequence of a reduction in lipolysis owing to an increase in energy supply from the products of digestion (Annison, 1960). Günzel and Giesecke (1974) reported that in sheep offered good quality hay ad libitum twice daily, plasma NEFA concentrations showed a definite pattern of diurnal variation, with the highest mean NFFA concentration before the morning feed and the lowest $4 \mathrm{~h}$ after it. In our experiment also the highest NEFA concentration was, for both groups, before feeding the concentrate and the lowest 4 to $6 \mathrm{~h}$ after.

In conclusion, feeding concentrate at $09.30 \mathrm{~h}$ instead of $16.00 \mathrm{~h}$ resulted in a higher total intake of OM i.e. total OM intake was higher when concentrates were given after rather than before a period of ingestion of hay. This suggests that feeding supplement after rather than before a major grazing bout may be an 
effective means of minimizing reduction in forage intake as a consequence of feeding concentrate. However, care must be exercised in extrapolating beyond pen-feeding situations, as grazing animals may respond to time of supplementation by altered ingestive behaviour (Howard et al., 1992). Therefore, further studies are necessary on the relationship between time of supplementation and diurnal pattern of herbage intake before general recommendations can be devised.

\section{Acknowledgements}

We are grateful to Dr P. Dewey of the Rowett Research Institute for carrying out the volatile fatty acid and ammonia analysis.

\section{References}

Allden, W. G. 1981. Energy and protein supplements for grazing livestock. In Grazing animals (ed. F. H. W. Morley), pp. 289-307. Elsevier, Amsterdam.

Annison, E. F. 1960. Plasma non-esterified fatty acids in sheep. Australian Journal of Agriculture Science 11: 58-64.

Arnold, G. W. 1981. Grazing behaviour. In Grazing animals (ed. F. H. W. Morley), pp. 79-104. Elsevier, Amsterdam.

DelCurto, T., Cochran, R. C., Harmon, D. L., Beharka, A. A., Jacques, K. A., Towne, G. and Vazant, E. S. 1990. Supplementation of dormant tallgrass-prairie forage. I. Influence of varying supplemental protein and (or) energy levels on forage utilization characteristics of beef steers in confinement. Journal of Animal Science 68: 515-531.

French, N. and Kennelly, J. J. 1990. Effects of feeding frequency on ruminal parameters, plasma insulin, milk yield, and milk composition in Holstein cows. Journal of Dairy Science 68: 1857-1863.

Günzel, R. and Giesecke, D. 1974. Der Einfluss der Fütterung, des Fastens und des Phlorhizindiabetes auf die Beziehungen zwischen Freien Fettsäuren und Glucose im Blut von Schaffen. Zentralblatt Veterinärmedizin A 21: 279-284.
Goering, M. K. and Van Soest, P. J. 1970. Forage fiber analysis (apparatus, reagents, procedures and some applications). Agricultural handbook, US Department of Aoriculture no 379.

Howard, M. D., Muntifering, R. B., Howard, M. M. and Hayek, M. G. 1992. Effects of time and level of energy supplementation on intake and digestibility of low-quality tall fescue hay by sheep. Canadian Journal of Animal Science 72: 51-60.

Kaufmann, W. 1976. Influence of the composition of the ration and the feeding frequency on pH-regulation in the rumen and on feed intake in ruminants. Livestock Production Science 3: 103-114.

Milligan, L. P. 1971. Fnergetic efficiency and metabolic transformations. Federations Proceedings 30: 1454-1458.

Ottenstein, D. M. and Bartley, D. A. 1971. Separation of free acids $C_{2}-C_{5}$ in dilute aqueous solution column technology. Journal of Chomatographic Science 9: 673-681.

Palmquist, D. L., Smith, L. M. and Ronning, M. 1964. Effect of time of feeding concentrates and ground, pelleted alfalfa hay on milk fat percentage and fatty acid composition. Journal of Dairy Science 47: 516-520.

Richardson, T. 1977. A modification of the Trinder Autoanalyser method for glucose. Annals of Clinical Biochemistry 114: 223-226.

Statistical Analysis Systems Institute. 1982. User's guide: statistics. Statistical Analysis Systems Institute, Cary, NC.

Stewart, C. S. 1977. Factors affecting cellulolytic activity of rumen contents. Applied Environmental Microbiology 33: 497-502.

Sulton, J. D., Hart, J. C., Broster, W. H., Elliott, R. J. and Schuller, E. 1986. Feeding frequency for lactating cows: effects on rumen fermentation and blood metabolites and hormones. British Joumal of Nutrition 56: 181-192.

Whitehead, R., Cooke, G. H. and Chapman, B. T. 1967. Problems associated with the continuous monitoring of ammoniacal nitrogen in a river water. Technicon symposium 1967, vol. 2, pp.377-380.

Zivin, J. A. and Snarr, J. F. 1973. An automated colorimetric method for the measurement of 3-hydroxybutyrate concentration. Analytical Biochemistry 52: 456-461.

(Received 27 September 1993-Accepted 24. March 1994) 